\title{
Land Ownership Patterns and Livelihood of Women Entrepreneurs: Implications for Sustainable Development in Ado-Odo Local Government in Ogun State, Nigeria
}

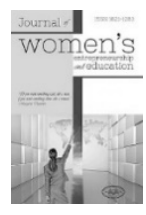

\author{
Olabisi S. Yusuff ${ }^{1}$ \\ Faculty of Social Sciences, Department of Sociology
}

\section{A B S T R A C T}

Land is an essential commodity everywhere in the world, for people who use it mainly as a source of livelihood, either for farming or other subsistence purposes... Women who are the primary users of land for farming faces challenges on owning landed properties as a result of their gender. Women entrepreneurs frequently and systematically lack access to land rights in many developing countries. Yet, land rights are keys for a life with dignity; for adequate standard of living, for economic independence and for personal freedom. This study therefore examined land ownership patterns and livelihoods of women entrepreneurs in Ado-odo local government of Ogun state. The paper was hinged on Social exclusion and feminist theory. Method of data collections was triangulated. Five hundred questionnaires were distributed to participants through multistage sampling technique, while 20 indepth interviewed were conducted for respondents that were purposively picked. Quantitative data was analyzed using simple percentage and frequency distribution. Hypothesis was tested with chi-square method. Qualitative data was analyzed through content analysis and ethnographic summaries. Findings from the study revealed that patterns of land ownership in Ado-Odo local government affects women entrepreneurs livelihoods and that majority of women respondents want change, as they narrated their challenges as regards patterns of land ownership. The paper recommends that for women entrepreneurs to have full access and rights

\footnotetext{
${ }^{1}$ E-mail: soyusuf@yahoo.co.uk, tel: 23407030386279
} 
Yusuff, O.S., Land Onwership Patterns and Livelhood, JWEE (2019, No. 1-2, 36-55) 37

to ownership of lands, there is need to deconstruct, re-construct, and reconceptualize customary law notions as they pertain to issues of land inheritance by women. This is important for sustainable development in Ogun state, Nigeria.

KEY WORDS patterns, land ownership, livelihoods, women entrepreneurs aocial exclusion. Nigeria

\section{Introduction}

In rural areas, land is the basis for agricultural production and the source for securing natural resources through fishing, hunting, pasturing or other activities. Land is used by many people for different purposes (e.g. for agricultural production, housing, industry, services and government). Land also has social, cultural and political functions related to each country's history. Land rights have broad impact on people's lives and livelihoods. These rights refer to the rules that specify who can do what with which resources and assets, for how long and under what conditions. Land rights increase women's powers in social, economic and political relationships. Rural women claim that a secured land right increases their social and political status and improves their sense of self-esteem, confidence, security and dignity" (Crowley, 2001). Land is therefore, vested in trusteeship with uncles and other male relatives, and is inherited by children when they become of age” (Eide, 2006).

There are several reasons to these constraints, for instance. The community orientation is that if women buy and own land under their names, they ultimately undermine family unity and ties. Women may feel they do not need their husbands. Part of the old practice is that if a woman wants to invest on land, such land should be bought in the husband's name, after which she can use the land as she pleases. Widows are often ejected by their in-laws out of the family land when their husbands die. Many women lose their rights to property after divorce or the death of a spouse. Women's socially sanctioned dependence on men, leaves them vulnerable to 'cultural traditions' that do not recognize women's ownership of land and other property. Men most often are willing to enforce such so-called customs. It is also emerging that some women who were themselves denied rights because of retrogressive practices uphold such practices to deny other women their rights” (Agarwal, 2003). 
However, this work tries to examine the effects of land ownership pattern in Ado-Odo local government area of Ogun state as women does not have much access to owning landed property, and how this poor access to land can affect livelihood, lack of food, and inability to make adequate sustenance provisions for their households. The land ownership system discriminates against women in many parts of the world, in traditional customary law, the wife is considered the property of the husband and so whatever she owns devolves to the husband. In addition a woman's continued interest in a property owned by her husband is dependent on two factors: Whether she bore children with the husband, or whether on the death of her husband she chooses to remarry a male relation of her deceased husband" (Caroline, 1995). It is therefore necessary to delve into the study of land ownership patterns and effects on women's livelihood in Ado-Odo local government areas of Ogun state with the view to examine the implications for sustainable development in the state. In view of the foregoing, the objectives of this study, therefore, include to
A. Examine socio-economic characteristics of women's entreprenuers in Ado-odo
B. Find out the effects of land ownerships on women's livelihood in Ado- Odo
C. Determine the challenges women faces on land ownership pattern in Ado-Odo
D. Find out women's perception on improving land ownership in Ado-Odo

\section{Brief Empirical Literature}

\section{Patterns of Land Ownership in Developing Countries}

Nwabueze (1972) sees land ownership pattern as the most comprehensive and complete relation that can exist in respect of anything. It is the fullest amplitude method of rights of enjoyment, management, and disposal over property. It implies that the owner's title to the rights is superior and paramount over any other rights that may exist in the land in favour of others. Ownership therefore connotes the totality of or bundle of the rights of the owner over and above every other person or thing. Tobi (1987) in affirmation views land ownership pattern as a method of collection of rights to use and enjoy property, including the right to transmit it to others. One fun- 
damental feature of ownership is the right of alienation of a property without seeking anybody's consent. A person owning a parcel of land has the right to take decisions on the land without consulting anybody.

Quan (2006) Land ownership pattern is the perception of having secured rights to land and property on a continual basis, free from unreasonable interference from outsiders, as well as the ability to reap the benefits of labour and capital invested either in use or rented to another. Thus, the way in which access to land is regulated, property rights are defined, and ownership conflicts are resolved has bread implications beyond the sphere of agriculture production (Deinniger and Binswanger, 1999).

Emeasoba, (2012) studied Land Ownership among the Yoruba of South West Nigeria: A Case for Women Land Inheritance. The researcher focused on the position of women's land inheritance and ownership rights in the South Western States of Nigeria and relates them to what is obtains in some selected societies in Nigeria and other countries. It then makes proposals on how to come out of the quagmire (inability of women to own land), and concludes that for law and policy to positively influence gender relations in the land tenure realm in these states, there is need to deconstruct, reconstruct, and re-conceptualize customary law notions as they pertain to issues of land inheritance by women.

Yusuff (2013) studied the challenges of women entrepreneurs in rural informal economic activities: implications for sustainable rural development in Ogun state, Nigeria. The researcher found that acquiring farmland is not easy thing around the study area. It was also discovered that the farmland although belong to the father, yet women has no legal rights to the farmland. The researcher also finds that when women want to buy land from indigenous owner, they are asked to bring their husband or brothers. On the other hand, the land owners will advise the women to plant only food crops. This position made the widow and divorced rural women to be more insecure as this vital means of production becomes more difficult.

\section{Conceptual Framework Interpretation}

Social exclusion theory is a process in which individual or peoples are systematically blocked, or denied full access to various rights, opportunities and resources that are normally available to members of the different group and which are fundamental to social integration and observance of human right, within that particular group example, Housing, Employment, 
Healthcare, Land use, Civic engagement, Democratic participation and due process.

Social exclusion theory is of the perspective that people are socially excluded from what is supposed to be their rights, like not having access to communal land. Women are deprived of their inheritance and recognition, because they believe they are in transit, i.e. they will get married some day; and go to their husband house. The customs and traditions oppress women and therefore created no room for access to communal or inherited land. Women are separated and are seen as inferior being when it comes to fundamental rights and this inequality affects their livelihood or income and access to land. Patriarchy, the dominance nature of man, and the level of education of women limits their access to land. These stumbling blocks or marginalization affects the livelihood of women. A woman who does not have access to these types of lands suffers; and is unemployed. Unemployed women cannot afford to rent or lease land, unless through gift which does not easily come by, while women who can afford to rent, lease, or purchased land are more educated, could be self-employed as they can use the land for different purposes. Likewise women, who are widowed, divorced, separated, and without a male child can only acquire land through rent, lease, gift or purchased. Women who are unemployed cannot acquire education; and know about land use act, and will not be able to pay levies or charges on acquiring government land.

However, to address this menace created by social exclusion in the society, the feminist theory came to play. Feminist theory is a movement that agitates for women's emancipation, equality, and equity in the society. From the feminist perspective, women for example, are denied access to land in some areas, through inheritance, deprived of their rights of inheriting their father's properties which might likely affect their livelihood. From the feminist paradigm, Women are separated, oppressed and intimidated and are seem as second class citizens, and not been equal to men in the society. Feminism came to fill the gap, which social exclusion created by fighting for the emancipation of women from marginalization, inequality to equity.

However, with this intervention, women, no matter their statuses will be able to acquire education, be gainfully employed, self-employed and will be able to purchase, rent, or lease land even if they cannot have access to the land through inheritance it is hoped that at the end of the study, some of these issues will be resolved through positive changes to land ownership, equity and equality to land ownership and inheritance. 
Yusuff, O.S., Land Onwership Patterns and Livelhood, JWEE (2019, No. 1-2, 36-55) 41

\section{Methods and Materials}

\section{Study Areas}

Ado-Odo/Ota Local Government Area is one of the 19 Local Government Areas of Ogun State, Nigeria. It came into existence on May 19, 1989, following the merging of Ota, part of the defunct Ifo/Ota Local Government with Ado-Odo/Igbesa Areas of the Yewa South Local Government. Ado-Odo/Ota borders on metropolitan Lagos. The Local Government Area is the second largest in Ogun State and it is headquartered at Ota (or Otta) at $6^{\circ} 41^{\prime} 00^{\prime \prime} \mathrm{N} 3^{\circ} 41^{\prime} 00^{\prime \prime} \mathrm{E}$ to the north of the Area. Other towns and cities include Ado-Odo, Agbara, Igbesa, Iju-Ota, Itele, Kooko Ebiye Town, Owode, Sango Ota etc. It has an area of $878 \mathrm{~km}^{2}$ and a population of 526,565 at the 2006 census. Being primarily agrarian in nature, the Local Government Area produces cash and food crops especially cocoa, kola nut, palm oil, coffee, cassava, timber, maize, and vegetables. Mineral resources include kaolin, silica sand, gypsum, and glass sand.

\section{Method of Data Collection}

Method of data collection was triangulated using quantitative and qualitative methods. Methods of data collection include structured questionnaire, and interview guide. Quantitatively, data was collected using multi stage sampling techniques. Five hundred questionnaires were distributed to rural women that engaged in farming activities. Qualitatively, twenty women farmers were purposively picked for in-depth interview. The questionnaire was personally administered to the respondents that were available at the time of this interview. The feed backs were also collected in the same manner.

\section{Method of Data Analysis}

The data collected from samples was arranged and organized into frequency tables. Responses to structured oral interviews were analyzed using content analysis, and ethnographic summaries. Responses to questionnaires were analyzed based on research questions and the data was placed on a frequency table and was analyzed using percentage and tables of illustration. The percentage and frequency are based on statistical order. The researcher then put into tabulation the data collected in pursuance of the main object of the study, testing of hypothesis and the outcome made necessary recommendation. The analysis was grouped according to the research objectives 


\section{Data Presentation and Analysis}

Table 1: Socio-Demographic Characteristics of the Respondents

\begin{tabular}{llrr}
\hline Statement & Variables & Frequency & Percentage \\
\hline 1. Age & $18-28$ & 51 & 10.2 \\
& $29-38$ & 101 & 20.2 \\
& $39-48$ & 86 & 17.2 \\
& $49-58$ & 60 & 12.0 \\
& 59 and above & 202 & 40.4 \\
& Total & 500 & 100.0 \\
2, Marital Status & Single & 207 & 41.4 \\
& Married & 227 & 45.4 \\
& Divorced & 10 & 2.0 \\
& Widow/Widower & 43 & 8.8 \\
& Separated & 13 & 2.6 \\
& Total & 500 & 100.0 \\
\hline 3, Religion & Christianity & 499 & 99.8 \\
& Traditional & 1 & 0.2 \\
& Islam & 0 & .0 \\
& Total & 500 & 100.0 \\
\hline 5. Number of Chil- & 1 & 19 & 3.8 \\
& 2 & 39 & 7.8 \\
& 3 & 62 & 12.4 \\
& 4 & 48 & 9.6 \\
& 5 & 32 & 6.4 \\
& 6 & 29 & 5.8 \\
& 7 & 18 & 3.6 \\
& 8 & 23 & 4.6 \\
& 9 & 10 & 2.0 \\
& 10 & 3 & 0.6 \\
& 11 & 1 & 0.2 \\
& No child & 216 & 216 \\
& Total & 500 & 100.0 \\
\hline
\end{tabular}

Source: Authors field work 2018

The findings shown in the table 1 goes thus; Ages of women in number and percentages, according to their responses, $51(10.1 \%)$ of the respondents were between the ages of $18-28$ years old, 101(20.0\%) are between the ages of $29-37$ years old, 86 (17 -.0\%) are between the ages of $39-48$ years old, 60 (11.9\%) are between the ages of $49-55$ years old, while 202 
(40.4\%) are between the ages of 58 years and above. This shows that those who are between the ages of 59 and above have the highest frequency. The implication of this finding was that there are older persons in rural areas than younger ones. The finding supported Olurode (1999) that demographically, rural areas are populated by older persons because younger ones had gone to rural areas in search of greener pastures

The findings showed that the highest number of respondents in the rural environment of Ado-Odo, are married women, 207 (41.4\%) of the respondents were single, 227 (45.4\%) are married, 10 (2.0\%) are divorced, 43 (8.6\%) are widow/widower, while $13(2.6 \%)$ are separated. This shows that those who are married have the highest frequency. The religion status of the respondents indicates that majority of the Ado-Odo women practice Christianity, 499 (99.8\%) of the respondents are Christians, 1 (.2\%) are traditional. This shows that those who are Christians have the highest frequency. The findings on number of children showed that respondents who have children have the highest frequency. 19 (3.8\%) of the respondents have just one child, 39 (7.8\%) have two children, 62 (12.4\%) have three children, 48 (9.6\%) have four children, 32 (6.4) have five children, 29 (5.8) have six children, 18 (3.6\%) have seven children, 23(4.6\%) have eight children, 10 (2.0\%) have Nine children, $3(0.6 \%)$ have ten children, while, $1(0.2 \%)$ have eleven children. A total of 284 respondents have children, while 216 respondents do not have children. The fertility rate is someone stable in rural areas. This may be because of poverty level and economic issues associated with rural populace.

Table 2: Patterns of Land Ownerships in Ado-Odo Community

\begin{tabular}{llrr}
\hline Variables & Statement & Frequency & Percentage \\
\hline Patterns of Land & Individual land Ownership & 10 & 2 \\
Ownerships & Government land Ownership & 40 & 8 \\
& Family Land & 210 & 42 \\
& Communal land ownership & 240 & 48 \\
\hline Do Women have & No & 500 & 100 \\
rights to inherit & Yes & 0 & 0 \\
land as their per- & & & \\
manent property & & 0 & 0 \\
\hline Inheritance of land & To Male and Female Children & 500 & 100 \\
in the community & To Male Children alone & 0 & 0
\end{tabular}




\begin{tabular}{llrr}
\hline Variables & Statement & Frequency & Percentage \\
\hline Do you have land & Yes & 106 & 21.2 \\
in your name & No & 394 & 78.8 \\
& Total & 500 & 100 \\
\hline Means of acquisi- & By Purchase & 85 & 80 \\
tions of land & A gift from husband & 06 & 5.6 \\
& Leasing & 15 & 14.1 \\
& Total & 106 & \\
\hline
\end{tabular}

Source: Author's Field Work (2018)

From the table 2, Community owns 48 percent of total land in the community. This means that everyone has rights to land in Ado-Odo local Government. Different traditional families' members own 42 percent of the land. Government acquired 8 percent of the land and individuals own only 2 percent of the land. This finding translated that family and community own more than ninety percent of Ado-Odo Land. Despite, the fact that each gender has rights of inheritance, women do not inherit land or entitled to inherit land from family or community. This is because of ethno-cultural beliefs system that women do not have rights of inheritance within her family and community. However, only $21.1 \%$ have lands in their names, while $78.8 \%$ do not have lands in their names. Among the $21.1 \%$ that have lands their names, $80 \%$ of them acquired the land through purchase, while $14.1 \%$ have access to the land through leasing either from families or community. The remaining $5.6 \%$ of them acquired the land as a gift from their husbands.

This was supported by some respondents in IDI session who said the following;

We do not practice individual ownership of land here, but communal ownership. One person does not own land here. It is a public property. "women are not entitled to inherit land in Ado-Odo community" she went further to say that "women can get land through other means like purchase, rent, and lease or through gift, but not through inheritance from their father. That's why stopping the deprivation is not an easy thing as the wicked ones amongst the men will not agree. (IDI/ female/49yrs/3 ${ }^{\text {rd }}$ March, 2018) 
Another respondent said: "woman are not entitled to inherit land in this community, land is not one man business, but the entire communities. we met it that way, and we get along with well, although sometimes the widows and women with no male children suffers intimidation and sexual harassment from men and their family members regarding land, as the men do demand for sex or ask women to give out their young female children to them for marriage, in other to be on their side in time of troubles, or giving them land to farm on, in exchange to sleeping with them. (IDI/female/40yrs $/ 3^{\text {rd }}$ march, 2018)

Another respondent said: "woman are not entitled to inherit land in this community, because of tradition, which made a woman a property to her husband, and therefore a woman should marry and go to her husband's house, where she will be recognized, and this recognition is based on her ability to have a male child for her husbands or else she will still be marginalized, and this tradition has been there before I was born, (IDI/female/39yrs/3 ${ }^{\text {rd }}$ March, 2018/)

Communal land ownership significantly limits and weakens' women's interest to struggle for liberation and their rights. Women cannot fight the whole men in the community, unlike in individual ownership of land, where one can easily struggle and get results from respective families. Communal land ownership also limits access to credit and productive resources, and thereby constrains options for self-employment in agriculture and social protection in times of shocks (FAO, 2010). It was observed that women are totally discriminated by denying them the right to own or inherit land from their parents, or spouse after the husband demise, unless the spouse has given them the land as a gift before his demise. Culturally, women are seen as properties that can be inherited and women that do not have male children suffer most from discriminations against land ownership. Findings of this study are line with the findings of Yusuff (2013), who in her study found that acquiring farmland is not easy thing around the study area. It was also discovered that the farmland although belong to the father, yet women has no legal rights to the farmland. The researcher also finds that when women 
want to buy land from indigenous owner, they are asked to bring their husband or brothers. Tradition supports this system of inheritance. This shows that all the respondents agreed that the system supports the gender discrimination on land. This is therefore supports the opinion of the social exclusion theory which states that women are totally excluded from certain things in the society. In order words, women are excluded when parents/family property are being shared. More broadly, many women face social exclusion. Moosa-Mitha (2012) discusses the Western feminist movement as direct reactions to the marginalization of white women in society. Women were excluded from the labor force and their work in the home was not valued.

Table 3: The effects of Land Ownership Pattern on Women's Livelihood using Education and Nutrition

\begin{tabular}{llrr}
\hline Statement & Variables & Frequency & Percentage \\
\hline Does this land ownership & Yes & 294 & 58.8 \\
pattern affect your in- & No & 206 & 41.2 \\
come? & Total & 500 & 100.0 \\
\hline Does your child or chil- & Yes & 235 & 50.0 \\
dren go school? & No & 218 & 43.6 \\
& No response & 47 & 9.4 \\
& Total & 500 & 100.0 \\
\hline Reasons & Poverty & 335 & 67 \\
& Parents' nonchalant & 108 & 21.6 \\
& attitude to child or & & \\
& children's education. & & \\
& Health related issues & 57 & 11.4 \\
& Total & 500 & 100 \\
\hline
\end{tabular}

Source: Authors fieldwork 2018

Analysis in table 3 Indicates that 294 (58.8\%) of the respondents were affected by land ownership pattern. This may be due to the facts that women farmers may not be allowed to plant cash-crop because the land does not belong to them. While 206(41.2\%) said they are not affected by land ownership pattern. Those not affected by landownership may engage in other economic trading activities. Despite lack of land ownership, which affected income, majority of the respondents $233(48.6 \%)$ of the respondents send their children to school, while 46(9.2\%) of the respondents don't send their children to school. This shows that majority of the respondents can afford their children's education. 
This shows that majority of the respondent's income are not directly affected by this land ownership pattern. This is because women already have idea of the culture so they prepare themselves ahead of time by engaging in other activities that will improve their livelihood; this was further buttressed by the respondents from IDI, who said as follows:

The culture is too harsh to women, it affects our income and livelihood indirectly, and although we are able to get along with the system, because we met it that way, I wished the custom will be abolished, in favor of both gender (IDI/ female/49yrs/ March, 2018)

There is peace with our culture, we don't want women to come and be causing problems with land inheritance this and that, from their marital homes. it does not affect our income. We are okay. We do many jobs to survive. Land or no land we have been surviving (.IDI/female/25yrs/march, 2018)

Land has long been recognized as key to advancing the socio-economic rights and wellbeing of women and their position in society (Rodernberg and Wichterich, 1999). Despite this assertion, women are still experiencing a lot of challenges concerning the issue of land ownership. For the majority of women in Africa, access to land is still linked to their relationship with a male family member and is forfeited if the relationship ends (Rodernberg and Wichterich, 1999). Radical Feminist argued that women's subservient role in the society was too closely woven into the social fabric to be unraveled without a revolutionary revamping of society itself (Yusuff, 2017). They believe women have been subjugated, and men primarily benefited from subordination of women in the society. They are exploited because they undertake free labour for men by carrying out childcare and house work and are denied access to positions of power Haralambos and Holborn (2003). 
Table 4: Nature of Livelihood using Nutrition

\begin{tabular}{llrr}
\hline Statement & Variable & Frequency & Percentage \\
\hline How many times do you & Three times & 306 & 61.2 \\
eat food daily? & Two times & 174 & 34.8 \\
& Once & 19 & 3.8 \\
& Total & 500 & 100.0 \\
\hline How often do you eat & Once & 129 & 25.8 \\
meat daily? & Two times & 255 & 51.0 \\
& Occasionally & 116 & 23.2 \\
& Total & 500 & 100.0 \\
\hline What is the main source & Pipe borne & 47 & 9.4 \\
of potable water? & Borehole & 278 & 55.2 \\
& Hand dug well & 1 & 0.2 \\
& Stream & 174 & 34.8 \\
& Total & 500 & 100.0 \\
\hline
\end{tabular}

Source: Authors fieldwork 2018

Indicates that 306 (61.2\%) of the respondents eats three times a day, 174(34.8\%) eats two times a day, while 18(3.6\%) eats once a day. This shows that majority of the respondents eats three times a day. How often do you eat meat daily? This showed that 129 (25.8\%) of the respondents eats meat once a day, 254(50.8\%) eats meat two times a day, 115(23.8\%) eats meat once a day, This shows that majority of the respondents eats meat two times a day. What is the main source of potable water? The study showed that 47 (9.4.\%) of the respondents have pipe born water as their source of potable water, 276(55.2\%) have borehole as their source of potable water, $1(0.2 \%)$ use hand dug well, $164(32.8 \%)$ gets their potable water from stream. This shows that majority of the respondents gets their potable water from borehole.

This was confirmed by IDI respondents

A respondent in in-depth interview has this to say," I eat food two or three times a day, depending on how hungry I am; but mostly three times a day. I also eat meat as I eat food unless the food does not require meat like tea and bread; but I eat meat mostly two or three times a day, or even more than. As for potable water, we have boreholes, and also we do fetch from other people's own when there no 
light; or we go to the stream. We don't have problem with water.

IDI/ female/49yrs/3 ${ }^{\text {rd }}$ March, 2018

The study shows that the women of Ado-Odo are hard working as they struggle hard to take care of their family. Even though Ado-Odo women are marginalized in terms of inheritance on land, which is the major source of livelihood in the society, they still struggles and fight to succeed within the context of harsh culture which they found themselves.

\section{Challenges of Women in Accessing Land in Ado-Odo Community}

According to Cooper (2010), gender discrimination in inheritance system is a violation of human rights and linked to asset stripping, poverty traps, intergenerational and trans-generational transmission of poverty. The custom does not recognized and acknowledged Joint acquisition of land by both spouses to give women some rights or privileges to land. Therefore women experiences deprivation, sexual harassment, intimidation, betrayal and the rest of them from men, this assertion was supported by some respondents in in-depth interview as they narrate their experiences;

A respondent narrated her ordeal,

"I witnessed in my family two orphans, ladies to be précised, being rubbed of their fathers land by our uncles, and ask them to go and get married, leaving them with no alternative than to go to court, and as God will have it the girls won the case in the court, but the problem is after settling in court, they still come home to face these set of people with this barbaric culture, and they are not ready to release these land, as they use every means, like poison or even diabolic powers to intimidate these girls". She also narrated another ordeal, as she said "A popular Nigerian actor from Ado-Odo, beside my house, collected land from widows forcefully and built mansion on it, not minding how this women feel and how they will cope". Efforts are also jeopardized even by the women themselves out of ignorance and different views of the tradition. 
(IDI/female/40yrs/3rdmarch, 2018/ Ado- Odo) Another respondent shed more light on these challenges:

I would have inherited many acres of land, as my father has many acres of land and we have only one male child, who leaves some acres to fallow, though I'm not regretting being a woman, because I can't blame God who created me to be one, but all I'm saying is that this culture is barbaric, and not favorable to the opposite sex, as some women don't give birth to male children, some women don't also marry at all, many women experience abuse physically, psychologically, emotionally and otherwise, because of the different harassments they get from men regarding this marginalization" we want change in the custom, if it should come, we will be happy.

(IDI/female/40yrs/, 2018)

Despite the clarity of the marriage laws, the rights of the widows are often not upheld in regular courts and almost never upheld in traditional courts especially in Ado-Odo and Yoruba land generally. Women's land rights are critically important. We know that they are correlated with increased empowerment and better outcomes for women and children (Rodernberg and Wichterich, 1999). The additional exclusion of women from access to land pushes them towards cities, where they often join the ranks of increasing number of women-headed households in slum area. According to Amanda (2007), A quarter of the world's 1.1 billion poor people are landless.

\section{Women's Perception on Improvement of Patterns of Ownership of Land}

Among peasant communities in Nigeria and Africa generally, land ownership has been the main assurance of their sustainability and livelihood (Odoemene, 2012; Daniel and Mittal, 2009; Oxfam International, 2011). For the various communities and individuals in this part of Nigeria, land is a treasured possession which is seen as the only enduring legacy an individual or community could bequeath posterity. Respondents were asked about their perceptions on how the patterns of land ownership can be improved. Several respondents expressed optimism on this issue: some respondents felt that it 
will be a waste of time to embark on such struggle. Some felt that women themselves were not ready to fight, that women are the enemies of themselves. Some expressed their opinions that land ownership patterns are cultural and men will do everything within their powers to preserve the culture.

Some respondents below illuminated on this issue:

A respondent in IDI had this to say

I don't know how this can be improved because it has been in existence before we were born so I feel it is only government that can come to our aid because even we the women do not have one voice. Some people will be scared, while some ho are willing to fight those does not have enough support to encourage them. So I feel its only government that can assist the women.

IDI/female/35yrs/April 2018/, Ado-Odo

Another respondent expressed her opinion on this:

We do talk about it in our gathering like the August meeting which is done once in every year but its not every member that indicates interest on the issue when it is been raised because they feel it is a waste of time and effort while some ignorant ones who are ignorant of the effects are in support. But they believe it is only the government and change of attitudes towards the women that can bring the desired change. So government should come to their aid through the traditional rulers and council of elders to have a change of orientation taking into cognizance the modern trend (IDI/female/40yrs/April, 2018)

SDC Gender Equality Network (2014); Monimart (2014) reported that different cultural discriminatory systems occur and a lack of understanding of land policies and laws often coexist and make it very hard for women to claim their rights. Women's rights to land often include inadequate legal standards and/or ineffective implementation at national and local level, because of weak institutions, as well as customary/religious laws and discriminatory cultural attitudes and practices. 


\section{Recommendation}

1. On the operational level, a community-based approach involving the whole community seems to be a crucial element for success in promoting equal rights to land. Community Leaders and religious and other leaders are key people who need to be consulted and guided even when perseverance and patience is needed.

2. Quotas and titling for women will be a useful strategy, but depend strongly on the context and always require acceptance by the community. Successful example such as favourable court cases can serve as a positive .example and encourage other women to fight for their rights. An international human rights framework is not sufficient to promote equal rights to land for women and men - and neither is a favourable legal framework on the national level. Related effectively functioning institutions and control mechanisms have to be in place and women and men need to know about their rights, as they need equal participation in decision making

3. Religious leaders should be carried along in the move for change as they can provide a veritable avenue for the dissemination of the idea. Federal state, local government and traditional rulers who are the custodians of culture, non-governmental organizations, men and women, are all needed to achieve the necessary change against the high level discriminatory practices on women's land inheritance and ownership. It may not be easy considering that in the final analysis the issue has to be legislated upon and passed into law and most of the legislators are men with their inherent biases.

4. Civil societies, especially non-governmental organizations, can play significant roles in ensuring that women have rights to land by advocating and supporting gender inclusiveness in national laws and policies, and in the development of land. They can also monitor, document, and publicize gender issues arising from land development. This should include raising awareness of the benefits of ensuring that women have input in managing and developing land, and publicizing violations of rights to land where applicable. Individuals and institutions involved in land law and administration can ensure that women have adequate input in decision making and that interpretations of custom that give greater recognition to women's rights are favoured over interpretations that give less recognition to them. Civil society 
Yusuff, O.S., Land Onwership Patterns and Livelhood, JWEE (2019, No. 1-2, 36-55) 53

groups can also play a role by increasing women's awareness of their rights and improve their access to justice.

\section{Conclusion}

\section{Pattern of Land Ownership and Women Livelihoods: Implications for Sustainable Development}

This study aimed at identifying land ownership pattern and livelihood of women in Ado-Odo community of Ogun State. The paper x-rayed the position of women's land inheritance and ownership rights in the community and how its effect on their livelihoods. This is to find out if land ownership pattern influences women's livelihood, there are many oppressive cultural practices that exits in various other parts of the country. Such practices include among others denial of land to women as inheritance and lack of interest to female western education among others. Less than $2 \%$ of the land available worldwide is owned by women (ActionAid 2010).

Under the Yoruba culture, women are regarded as inferior to men. This attitude is reflected in all facets of life, be it social, economic or political. The predominance of patriarchy in law, policy and practice in the political zone ensures that land has owners but they are not women. Women are even seen as properties inheritable by men. The findings of this work validated this assertion. It was discovered in this work that majority of the population that made up Ado-Odo community believes that there is relationship between land ownership pattern and their livelihood.

Culture is its self-dynamic and not static, as the issue of women inheriting and owning land has achieved global attention with both national and international women summits clamoring for change. This means that the importance of women land inheritance rights cannot be over emphasized if women are given equal opportunity. It would facilitate increase in economic opportunities, encourage investment in land and food production, and improve family security, fight poverty and achieve sustainable development. This paper argues that land is essential to secure a livelihood, especially for rural people, and to reduce poverty in other to promote sustainable development. Equal rights to land must therefore be an unchallenged asset in the new post-2015 development framework. The most common way to achieve equal access for women and men to land as well as control over it are land tenure reforms (FAO 2010; Pallas 2011) . 


\section{References}

[1] Action Aid. 2010. Her Mile: Women's rights and access to land. The last stretch of road to eradicate hunger. Rome, Action Aid

[2] Agarwal, B. 2003. "Gender and Land Right Revisited: Exploring New Prospects via the State, Family, and Market”, Journal of Agrarian Change, Vol. 3 Nos. $1 \& 2$ pp 184-224.

[3] Amanda, R. 2017. Threats to Women's Land Tenure Security and Effectiveness of Interventions - Annotated Bibliography

[4] Caroline, S. 1995. Global trends in Land Tenure Reform: Gender Impacts. Routledge Publishers

[5] Cooper, E. 2010 .Inheritance and Intergenerational Transition of Poverty in Africa: Policy Consideration

[6] Crowley, E. 2001. Land right: vision 2020 empowering women to achieve food security. Brief 2, August, 12, 2001, pp 1-3.

[7] Deininger, K. 2011. Challenges posed by the new wave of farmland investment. Journal of Peasant Studies 38(2): 217-247.

[8] Eide, A. 2006. Promoting economic, social and cultural rights: Obligations of states

[9] FAO. 2010. Report to “The New Partnership for Africa's Development” land and water Resources Issues and Agricultural Development 22nd Regional Conference for Africa, Cairo, 4-8th February and accountability of non-state actors, p. 5

[10] FAO. 2010: Gender and Land Rights. Understanding Complexities; Adjusting Policies. Economic and Social Perspectives Policy Brief 8.Rome, FAO.

[11] International Land Coalition (ILC). 2011. Strategic Framework 20112015. Rome. A Transformative stand-alone Goal on Achieving Gender Equality,

[12] Haralambo and Holborn. 2002. Sociology Theme and Perspective. London Harper Collins

[13] Nwabueze, B.O. 1972. Nigerian Land Law, Enugu, Nwamife Press, Nigeria

[14] Odoemene, A. 2012. "Land Grab Conflicts in Africa: Engaging Landscapes of Resistance and Alternatives”, Research Proposal Presented for the African Peace Building Network (APN) Fellowship Competition of the Social Science Research Council (SSRC), New York (June).

[15] Oxfam International. 2011. "Bio-fuelling Poverty: Why the EU Renewable- Fuel Target May be Disastrous for Poor People.” (Oxfam Briefing Note (November 1)

[16] Pallas, S. 2014. Women's Land Rights: The Key to Sustainable Development Food and Agriculture Organization of the United Nations.

[17] Quan, J. 2006. Land Access in the 24th Century; Issues, Trends, Linkages and Policy Options .Food and Agriculture Organizations, Rome. 
Yusuff, O.S., Land Onwership Patterns and Livelhood, JWEE (2019, No. 1-2, 36-55) 55

[18] Rodernberg. B., and Wichterich, C. 1999. Empowerment: A study of the Women's Projects Abroad Supported by the Heinrich Boll Foundation. Berlin: Heinrich Boll Foundation

[19] Tobi, N. 1987. Nigerian Land Law Nigeria, Ahmadu Bello University Press. Nigeria

[20] Yusuff, Olabisi. S. (2015) The Challenges of Women Entrepreneurs in Rural Informal Economic activities: Implication for sustainable Rural Development in Ogun State, Nigeria. In Olutayo, A.O. Omobowale, A.O and Akanle, O. Contemporary Development Issues in Nigeria. Cambridge Scholars Publishing.UK.

Article history: $\quad$ Received: 4 December, 2018

Accepted: 8 May, 2019 